\title{
Framing an Accusation in Dialogue: Kafka's Letter to His Father and Sarraute's Childhood
}

\author{
Lorna Martens
}

University of Virginia

\begin{abstract}
Kafka in the Letter to His Father mimics a courtroom trial with pleadings and rejoinders; Sarraute in Childhood tells her story in the form of a dialogue between herself and an initially confrontational, later complicit interlocutor. Curiously, both autobiographical texts have accusatory agendas. Kafka levels an accusation against his father, Sarraute against her mother. Following Rousseau, autobiographies that accuse others and/or vindicate the self are not rare, but the art of accusation is delicate: in order to stick and not boomerang on the writer, the accusation must be persuasively delivered. This paper examines how Kafka and Sarraute, both lawyers by profession, balance the dialogue form and the accusation. It is argued that each writer uses his or her version of the dialogue tactically, to accuse the parent while camouflaging the accusatory agenda, but in the end to win the case.
\end{abstract}

Keywords: Franz Kafka, Letter to His Father; Franz Kafka, Brief an den Vater; Nathalie Sarraute, Childhood; Nathalie Sarraute, Enfance; autobiography; dialogue

Inasmuch as it depends on a readership, life writing is intrinsically dialogic. Frequently, however, autobiographers pursue a monologic agenda. They write to vindicate themselves, accuse others, or both. The autobiographer does not intend to open a discussion but, rather, to shut down debate. He or she hopes to have the last word, one that brooks no retort. Rousseau, claiming to speak the truth about himself, set the precedent for the type of "confession" that exonerates the autobiographer while 
inculpating others. Hoping to have the final word, one that would render the insinuations, jabs, and counterpositions of his contemporaries forever null and void, he represented himself as an injured innocent, unjustly maligned and persecuted. The truth claim of autobiography abets this type of monologic agenda. Wielding the truth, the autobiographer purports to tell an incontrovertible story. As soon as an autobiography is published, however, the self-vindication or the accusation becomes dialogic after all, since it depends on readers' acceptance.

The art of accusation is particularly delicate. The shrill voice of the complainer is not necessarily one that induces a reader to go on reading. Readers have a limited appetite for whining, while anger is unattractive, whether justified or not. As Bertolt Brecht perceptively observed in his poem "To Posterity": "Even hatred of baseness distorts a person's features. Even anger against injustice makes the voice hoarse." Revenge motives in autobiography are easily sniffed out. In order to stick and not boomerang on the writer, therefore, an accusation must be artfully and persuasively delivered.

Families turn a sharp ear toward autobiographies. Countless autobiographies have raised the ire of families. This is particularly true if the autobiographer airs indiscreet details or utters harsh words about family members. For example, Enid Starkie's excessively candid A Lady's Child (1940) was, according to her biographer, badly received in Dublin as "an unpardonable piece of disloyalty" (The Irish Times) and prohibited. This increased interest in it, so that it was republished. An unpardonable sequence of events: "Her relatives resented it fiercely," her biographer emphasizes. ${ }^{2}$ Why not work out family quarrels behind closed doors? Why air dirty linen in public? If an autobiographer wants to trample on filial piety and criticize a parent in print without suffering consequences, he or she would do well to wait until the parent is dead. Many do just that. Athénaïs Michelet, an early example of a woman autobiographer fanned by mother hatred, waited to start writing her autobiography until a few months after her mother's death. ${ }^{3}$ If the offending parent lives to extreme old age, then it is prudent to postpone publication at least until he or she is beyond the age of reprisal. Claire Martin, whose autobiography In an Iron Glove (1965) is meant as an exposé of her abusive father, states that she had been preparing herself to write it for years. ${ }^{4}$ But she held off until her father was an old man, "defenseless, frail, pitiful, at the mercy of others as much as any child." ${ }^{5}$ In his 90 s, he died two days after the book's publication. ${ }^{6}$

Are there rhetorical strategies for framing an accusation so that it seems meeker, milder, more acceptable to the accused (if it is intended to be read by that person), and/or more convincing to third parties (if it is intended for publication)? Based on autobiographical writing by Franz Kafka and Nathalie Sarraute, both of whom were lawyers by profession, 
I propose that one such way is to frame the accusation as an imaginary dialogue. In this scenario, the autobiographer pretends to relinquish the reins. He or she divests the autobiographical "I" of its sole authority by building in a contrasting point of view.

Franz Kafka in Letter to his Father (written in 1919) and Nathalie Sarraute in Enfance (published in 1983) both employ the device of an imaginary dialogue to frame an accusation against a parent. The two works are differently situated, inasmuch as Kafka never intended the Letter for publication, whereas Sarraute did publish her childhood autobiography, albeit after her mother was long dead. Kafka's Letter was published after his death, like so many of his other manuscripts that he also did not intend for publication, if one can believe the two wills which he addressed to his friend and executor Max Brod. In them he ordered Max to burn everything. According to Brod's biography of Kafka, Kafka told him in conversation that he meant the Letter, which he addressed to his father, to be given to his father via the intermediary of his mother. By writing the Letter and having his father read it, Kafka hoped, in Brod's words, to "clarify his awkwardly faltering, painfully encrusted relationship with his father." In Brod's opinion, the Letter would have had the opposite effect. According to Brod, Kafka did give the Letter to his mother, but in the end she did not give it to her husband, but returned it to Franz. ${ }^{8}$ Hartmut Binder, however, reasons that Kafka did not give the letter to his mother (though he could have shown her parts of it), because he did not finish typing it up; the last $2 \frac{1 / 2}{2}$ pages remain in his handwriting. ${ }^{9}$ The fate of the Letter resonates curiously with the themes of failed communication and the failure to achieve a goal that mark Kafka's entire oeuvre. In any event, Kafka never meant the Letter for the public, but at most hoped to secure with it a receptive audience in his father.

Kafka and Sarraute not only intended their works for different audiences, but they concocted different types of dialogues, involving dialogue partners who play different kinds of roles (though both partners are combative). Kafka's Letter is precisely that: a letter. He addresses it to his father, the accused himself. He embeds in it an imaginary dialogue between himself and his father, in which he also assumes the role of moderator, thereby triangulating the give-and-take. Sarraute's work, whose real addressee is the public, engages a different dialogue partner: not her deceased mother, but a present-day interlocutor, a voice the elderly author is talking to in present time. Sarraute does not identify this interlocutor. The narrator, i.e., the "Sarraute-the-autobiographer" figure, declares herself interested in pursuing her memories of childhood, and this is exactly what she does. She tells the interlocutor about her childhood from her earliest memories, starting at age 2, until the age of 12. Her narrative, which for the most part follows an approximate chronological 
order, is very similar to a classic childhood autobiography, except that she addresses an interlocutor, who reacts, asks questions, gives opinions, and so forth throughout the entire text.

Kafka's and Sarraute's works lie over sixty years apart. Father-son conflicts were widespread among German writers of Kafka's generation, as the biographies of Frank Wedekind, Georg Heym, Walter Hasenclever, and Johannes R. Becher, among others, attest. ${ }^{10}$ By the time Kafka wrote his Letter, such conflicts had not only been underwritten by psychoanalysis, but had found spectacular literary expression in Walter Hasenclever's drama Der Sohn (1914), which elevated a personal conflict into a struggle between a new, idealistic future and the bankrupt values of the bourgeois past. Kafka's own "father problem" was typical of his time inasmuch as an artistic son confronts a domineering bourgeois father, but it cannot be considered to have been derivative of a trend. It was plainly personal and deeply felt. Father-son antagonisms inform fiction that Kafka wrote prior to the Letter.

Nathalie Sarraute wrote her childhood autobiography in a different climate. By the time Sarraute wrote Enfance, daughters' animosity toward their mothers had come into fashion, somewhat in arrears of men's conflicts with their fathers, and then had gone back out of fashion. Thus, by the mid-1930s women, who had hitherto been largely respectful of their mothers at least in print, started to feel free to publish acid criticisms of them in their autobiographies-witness the example of the outspoken Mabel Dodge Luhan, whose scathing representation of her family, including her mother, in her Intimate Memories: Background (1933) was said to have hastened her mother's death, even though her mother had given her permission to publish the book. ${ }^{11}$ But the feminist 1970s put a halt to this maternophobic trend. "Hating one's mother," observed Elaine Showalter in 1979, "was the feminist enlightenment of the fifties and sixties; but it is only a metaphor for hating oneself."12 In the 1970s the mother-daughter relationship was extensively theorized. ${ }^{13}$ The overall trend was to upgrade and celebrate femininity, including maternity. Unexamined mother hatred became démodé. Writing in the early 1980s about her relationship with her mother, Sarraute confronted the problem of too much theory. The independently-minded writer had to find a way to stand apart, to preserve the individuality of her unusual childhood and her idiosyncratic relationship with her mother amid the swirl of theory, to maintain her originality as a writer. Moreover, straightforward mother criticism risked being ill-received. This may indeed have been one of the reasons why she chose to mount her accusation indirectly, through the form of a dialogue.

By the time Sarraute wrote Enfance, Kafka's Letter was famous and had found literary echoes. In 1947 Sarraute published an essay entitled "De Dostoievski à Kafka," in which she interprets Kafka, contrary to the contemporary 
trend, as Dostoevky's legitimate heir. ${ }^{14}$ She does not mention the Letter for the good reason that she could not have known it; it was first published five years after the appearance of her essay. Yet given her admiration for Kafka, it seems likely that she would eventually have read it. Was Sarraute inspired by Kafka's Letter when she conceived of the form of Enfance? It is likelier that she independently had the idea of staging her autobiography as a dialogue. Leah Hewitt has discussed Sarraute's affinity for dialogue in her earlier work as a means of weaving together conflicting points of view, arguing that Sarraute's use of dialogue in Enfance continues a trend. ${ }^{15}$

Both Kafka and Sarraute, I argue, use the dialogue form as a mitigating device. But in keeping with their different intended audiences, each writer uses it differently. Kafka could at most fear that his father would reject his point of view, and that was nothing new. Sarraute had nothing to fear from family in publishing her autobiography, but needed only to consider her audience. Kafka uses the dialogue form to cushion the accusation, Sarraute to distract from it.

"Dialogue," writes James M. Honeycutt, "reflects empathy, while monologue is egocentric." ${ }^{16}$ Classic dialogue theory (Buber, Bohm) advances an idealistic view of dialogue. Martin Buber distinguishes between "genuine" dialogue, which involves a "turning towards the other," and other forms of dialogue, namely technical dialogue and monologue disguised as dialogue. ${ }^{17}$ This last type, the monologue disguised as dialogue, establishes not the "I-Thou" relationship of dialogue, but an "I-It" relationship, or as Honeycutt puts it, "you think of the other person as an object to be labeled, manipulated, changed, and maneuvered to your own belief." 18 In short, dialogues can conceal monologues. David Bohm, who likewise holds an idealistic view of dialogue, proposes that "dialogue," unlike "discussion" and "negotiation," is a form of communication in which "nobody is trying to win." ${ }^{19} \mathrm{He}$ defines the word "dialogue" with the positive connotation of listening to others' opinions, suspending judgment, and seeing "what all that means": "If we can see what all of our opinions mean, then we are sharing a common content, even if we don't agree entirely." ${ }^{20}$ For Bohm, a "dialogue" must not envisage a practical decision as its outcome: "In the dialogue group we are not going to decide what to do about anything. This is crucial. Otherwise we are not free. ... It's open and free. It's an empty space." 21

"Internal dialogue," or as Buber calls it, the "so-called dialogue with oneself," is also a notion that has been debated. ${ }^{22}$ The phenomenon has attracted interest in psychology as well as in philosophy. Honeycutt, a psychologist, classifies internal dialogues as one type of "imagined interactions" and shows on the basis of empirical studies that people engage in imagined interactions a great deal: sometimes proactively, to anticipate 
real encounters, and sometimes retroactively, to review what happened during an encounter. Data suggests, unsurprisingly, that "imagined interactions" are dominated by thoughts of significant others and most commonly involve conflict. ${ }^{23}$ Honeycutt asserts that imagined interactions may enhance perspective-taking on a conflict situation: "At its most base level, IIs [imagined interactions] facilitate thinking about other's [sic] messages rather than being egocentric." ${ }^{24}$

Kafka's Letter hovers between a real missive and an imagined dialogue. It is a real missive-but one he never delivered to its addressee. Whether he intended for it to reach its addressee, or initially intended it for his father but then changed his mind, is, as we have seen, a matter of debate. Kafka was a prolific letter-writer. Indeed, Deleuze and Guattari dub his devotion to the epistolary genre vampiristic, inasmuch as they believe that Kafka was deeply invested in writing letters: "letters must bring him blood." ${ }^{55}$ On top of this, Kafka himself held an idiosyncratic epistolary theory, articulated in a letter to Milena in 1920, in which he himself suggests the notion that letters carry blood. But this blood, according to him, never reaches its intended recipient, because it is intercepted by ghosts. The passage deserves to be quoted at length: "Writing letters is actually an intercourse with ghosts and by no means just with the ghost of the addressee but also with one's own ghost, which secretly evolves within the letter one is writing... How did people ever get the idea they could communicate with one another by letter! ... Writing letters ... means exposing oneself to the ghosts, who are greedily waiting precisely for that. Written kisses never arrive at their destination; the ghosts drink them up along the way." ${ }^{26}$ According to this highly skeptical view of epistolary communication, the letter-writer constructs a ghost of the other to which he then communicates, in the process creating a ghostly Doppelgänger of himself. The attempt to communicate with an actual other person is in vain, for neither letter writer gets any "kisses" (Kafka substitutes "kisses" for the blood that ghosts legendarily thirst after). Kafka's Letter to His Father actually does manifest an eerie correspondence with this epistolary theory, inasmuch as it does indeed construct a ghostly father; it even gives his father a voice. In any case, the Letter can hardly be considered a naive outpouring, and although Kafka may initially have hoped to improve relations with his father by writing it, he was also presumably skeptical about its chances for real-world success.

To return to dialogue theory, the Letter, interpreted as a real missive, is fundamentally monological, in Buber's sense. Kafka is at pains to represent his point of view and get his points across. The Letter is also purposive, which according to Bohm a dialogue may not be. It poses as a dialogue in order to effect something. Kafka would like to gain his 
father's understanding for his point of view. Initially the letter envisages a hopeful outcome. Nevertheless, the Letter is not a dialogue in Bohm's sense but, since it has an agenda, more closely resembles the first step in a negotiation.

Kafka's Letter has received intense scrutiny from criticism, but it has mainly been seen as a source of evidence about his life and literary oeuvre. ${ }^{27}$ In the Letter Kafka represents himself as one who was dominated, downtrodden, and overshadowed by his father all his life. Moreover, he states, "My writing was all about you." ${ }^{28}$ In light of such stories as "The Judgment" and "The Metamorphosis," which involve father-son conflicts, this statement is extremely plausible and supports an autobiographical interpretation of these works. In these two stories, each of which ends badly for the son, the father figure not only shows no understanding for the son, but actually seems to batten on the son's predicament. The adult son's dilemma causes the elderly father to reassert himself and gain strength and power, not in order to help the son, but to confront him as an antagonist.

If the reader of Kafka's long Letter to His Father takes away one main point, it is that Hermann Kafka, Franz's father, intimidated Franz, and that Franz suffered his entire life from his father's overbearing behavior. Kafka wrote the Letter at age 36, in 1919, following his father's opposition to his engagement to Julie Wohryzek. One of the most interesting aspects of the Letter is that Kafka does not just represent his own point of view, but reconstructs, in a seemingly insightful and fair way, his father's. The letter plays out as a dialogue, with accusations and rejoinders. It quickly comes to resemble a court case, in which Kafka and his father alternately have their say as prosecution and defense. Kafka himself confided to his Czech translator Milena Jesenská, to whom he promised to give the letter the following summer, that the letter was full of "lawyerly artifices." ${ }^{29}$ Kafka appears to bend over backward to represent his father's position. He gives his father's point of view-namely, that his father finds Franz ungrateful for his many sacrifices-first, before he presents his own views. By giving his father "air time," Kafka risks "losing" his "case"—and indeed, some readers react to the letter by deeming Franz a spoiled brat. But most find that Franz gains more points than he loses by demonstrating that he understands his father's point of view. He takes on the role of judge - a benevolent judge. If Franz was terrified of his father all his life, Kafka is at pains to point out that this is less the fault of the father than of the sensitivity of the child. He writes: "I never, and not even for a single moment, believe any guilt to be on your side.... I was a timid child.... Not every child has the endurance and fearlessness to go on searching until it comes to the kindliness that lies beneath the surface" (Letter: 15) Two 
opposite natures, Kafka argues, produced an unfortunate syndrome that persisted. As judge, Kafka graciously concedes that both parties are guiltless and advocates amnesty: "I too believe you are entirely blameless in the matter of our estrangement. But I am equally entirely blameless. If I could get you to acknowledge this, then what would be possible is-not, I think, a new life, we are both much too old for that-but still, a kind of peace" (Letter: 9). Viewed as an imagined dialogue, the Letter thus does start with an effort at taking perspective. It does start by proposing something akin to Bohm's idealistic view of dialogue, cited above: Kafka and his father can "share a common content, even if [they] don't agree entirely."

As if this were not enough by way of deference, Kafka writes his father's putative rejoinder at the end. His father, in this imagined rejoinder, sees through Franz's strategy and mocks him, saying, "What appears between the lines, in spite of all the 'turns of phrase' about character and nature and antagonism and helplessness, is that actually I have been the aggressor, while everything you were up to was self-defense. ... You have proved three things: first, that you are not guilty; second, that I am the guilty one; and third, that out of sheer magnanimity you are ready not only to forgive me but... also to prove and be willing to believe yourself that-contrary to the truth-I also am not guilty" (Letter: 121-123). Kafka thus lets his father demolish his argument. This demolition, however, allows Kafka to make the further point that he, not his father, is the real author of the rejoinder: "My answer to this is that, after all, this whole rejoinder-which can partly also be turned against you-does not come from you, but from me" (Letter: 125). Kafka's final point is that his authorship of his father's rejoinder proves that his self-mistrust, which his father instilled in him, is immense: "Not even your mistrust of others is as great as my self-mistrust, which you have bred in me" (Letter: 125). Kafka therefore ends the letter by affirming his position as creator, while accusing his father one last time, this time of having robbed him of all self-confidence.

In the long middle section of the Letter, the imaginary dialogue Kafka constructs in the opening pages cedes to monologue. Franz represents his own point of view at great length. A great deal of accusation is involved, and the accusation veers ever more into a sick antagonism. In particular, toward the end Kafka accuses his father of something he cannot possibly legitimately accuse him of, his own failure to marry.

Not just this long middle section where Kafka articulates his own complaints, but the final pages of the Letter as well, the pages that Kafka never typed up, corroborate that the Letter, whether viewed as a real letter or an imagined interaction, is fundamentally an accusation. The dialogic beginning, which stages pleadings as if before a court of law and implies that Kafka and his father are equal before the law, is a mitigating strategy. 
The dizzying end, whose twists are hard to follow, ultimately represents a renewed self-assertion and a return to accusation. This coda, which starts with an abject self-undercutting (his father's "rejoinder"), flips into the opposite mode when the author stops the spiral of infinite regress with a rhetorical foot-stamp, asserting that after all he himself, Franz, is the author of the entire ambivalent and self-doubting letter and that his father is entirely to blame for his ambivalence and self-doubt. By "losing" his "case," Kafka thus covertly wins his case. Although he follows this final accusation with some concessive words that return to perspectivetaking and emphasize the complexity of the truth, his last three sentences mainly make the impression of seeking a way to close on a conciliatory note, now that all that needs to be said has been said.

Kafka's description of the letter as full of lawyerly artifices corroborates that his dialogic construction of the Letter was a strategy. If we assume that Kafka at first intended to deliver it, the Letter does seem to represent a relatively gracious way of pointing out to his father that he, Franz, also has a point of view. This is really all the Letter is asking the father to acknowledge. As for the actual reader, who never was intended to read the Letter, Kafka appears ultimately to win, less by convincing the reader that his position has more merit than his father's than by impressing the reader with the passion, energy, and thought that he put into writing this extremely long letter, in which he describes himself as a person who was essentially paralyzed in every domain in which his father dominatedmarriage, family, life itself-the one exception being the little island that he occupied alone, writing. His account of the ongoing pain he suffered because of his father is heartfelt. It shines through the argumentation and tips the balance.

Over sixty years later, Sarraute's formally innovative childhood autobiography Enfance, which appeared in the first French edition when the author was 83 , makes complex use of the dialogue form. In this seemingly unpretentious yet in fact highly sophisticated and much commented-on work, Sarraute produces her account of her childhood in the form of a conversation between a narrator (herself) and an interlocutor. ${ }^{30}$ She thereby circumvents and subverts the classic format for autobiography, in which an older, wiser, authoritative narrator tells the story of his or her unwise younger self. Why? The interlocutor device is ingenious and serves several useful purposes. First and most obviously, a dialogue suggests that potentially there exists more than one point of view. Second, the dialogic format, together with the present as the principal tense of narration and Sarraute's insistent use of ellipses to indicate that thoughts are trailing off, creates the impression that the account of childhood is emergent, rising before the narrator's eyes even as she speaks. This gives her work a 
tentative, unfinished air. In sharp contrast to a ponderous retrospective monologue, the give-and-take of the dialogue stages autobiography as an ongoing process of remembering rather than as the finished product of memory congealed into fact.

Third, Sarraute uses the interlocutor to suggest a complex conception of self that is more adequate to the psychoanalytic climate in which she wrote than the traditional form of autobiography. The interlocutor is not a static personality, but changes in nature, function, and even gender, as Lejeune points out, ${ }^{31}$ so that the reader is successively tempted to identify him or her as a psychoanalyst, a friend, and an alter ego. At the beginning of the dialogue, the two voices are distinctly different. The work begins in medias res with the interlocutor speaking: "-Then you really are going to do that? 'Evoke your childhood memories' ... How these words embarrass you, you don't like them. But you have to admit that they are the only appropriate words. You want to 'evoke your memories' ... there's no getting away from it, that's what it is." The author figure responds, "Yes, I can't help it, it tempts me, I don't know why..."32 The interlocutor voice is critical, distanced, and skeptical, whereas the author voice is impulsive and reluctant to listen to demurrals. The two continue in this vein for some time. Later in the book, the interlocutor speaks less, loses his (or her) distinct voice, and finally produces information that only the author could know, so at that point at latest, the alter ego interpretation is clinched. Since the interlocutor both is and is not the self, Sarraute suggests that the self is heterogeneous, codependent on and co-constituted by othersan insight that accords with what the age of psychoanalysis believed about the self. As Serge Doubrovsky argues, psychoanalysis has taught us that the "self-portrait is in fact a hetero-portrait which comes to [the author] from the realm of the Other." ${ }^{33}$ Sarraute professed to detest psychoanalysis. ${ }^{34}$ She wanted to explore psychology on her own in her writing. The authors she admired most were Proust, Joyce, and Woolf, and she aspired, like them, to devise innovative techniques to represent psychic states and processes. She developed an original psychological idea of her own, the tropisme or involuntary subverbal response. In all of her work, including Enfance, she sought to capture such responses in language. Nevertheless, she wrote in the era of psychoanalysis, and Enfance bears the stamp of psychoanalysis, both in the construction of the interlocutor figure and in Sarraute's conceptualization of the workings of memory as unreliable.

Fourth and last, but not least, the interlocutor device helps Sarraute accomplish a specific agenda while she appears, misleadingly, merely to be recovering her memories of childhood with no agenda whatsoever. She mounts an irrefutable case against her mother, who is represented as charming but narcissistic and unloving. Her mother, we eventually learn, 
packed her 8-year-old daughter, her only child, off to live with her father in Paris while she remained in Russia with her new husband, and did not attempt to see her for $2 \frac{1}{2}$ years. But Sarraute unfolds this case strategically, and on first reading imperceptibly, as a gradual process of uncovering childhood memories. The interlocutor device is instrumental in getting her agenda underway. The interlocutor prods her to uncover repressed memories. The narrator herself stresses from the outset that she adored her beautiful mother, who exercised a sovereign power over her imagination. The interlocutor here at the beginning of the text is confrontational, argumentative, and skeptical. He-for at this point he is gendered masculinesounds like a psychoanalyst. As Freud's Dora case shows us, a psychoanalyst can behave much like a prosecuting attorney; psychoanalytic dialogues and court cases have some overlap. Sarraute's interlocutor pushes, challenges, and probes, hinting at a deeper meaning behind the narrator's earliest memories. In particular, he pounces on one portentous early memory: the narrator's memory of her mother pretending to wrestle with her new husband Kolya. The interlocutor asks her particularly skeptical and probing questions about it. In this episode, the child tries to defend her mother from Kolya, but her mother gently pushes her away, saying, "Husband and wife are on the same side" (Sarraute: 62). The implication, which the child does not fully grasp at the time, is that the child is an unwanted outsider who is interfering in her mother's and her stepfather's loving game. To the adult narrator, the incident flashes up like a screen memory, signaling what will later become certainty about her mother's lack of love for her. The interlocutor prods the narrator to admit, "I was a foreign body... who was in the way..." The interlocutor pushes on: "Yes: a foreign body. You couldn't have put it better. That's what you felt then, and with such force... A foreign body... Sooner or later, the organism it has infiltrated will eliminate it..." The narrator protests: "No, not that... I didn't think that..." The interlocutor concedes: "Not think, of course not, I'll grant you that... but it appeared, indistinct, unreal..." The narrator continues to protest: "No, you're going too far..." But the interlocutor has the last word: "Yes. I'm staying very near, and you know it." (Sarraute: 64-65) The Nachträglichkeit (Freud's term for delayed action or après-coup) that is operative in this episode models the reader response- the hindsight, the retrospective reevaluation-that the construction of Childhood will encourage generally. At this point in the text, however, the impulsive, yet tentative and self-questioning narrator can hardly be suspected of having an agenda, and the interlocutor himself, with his very initial contrariness, distracts the reader from such a suspicion. The interlocutor decoys the reader away from Sarraute's agenda. The intrigue at first appears to be between the narrator and the interlocutor, not between Sarraute and her mother. 
Once the narrator's memories reach the point when her period of exile in France begins, after her mother sends her to live with her father and stepmother in Paris and her troubles begin, the interlocutor changes in function. S/ he becomes more of a simple listener and cooperative collaborator in Sarraute's reconstruction of events and interpretation of her tale of woe, until it becomes plain that she is a second voice within Sarraute herself.

Since an authoritative narrative voice is lacking in this autobiography, there is a corresponding absence of declarative statements, definitive interpretations, and conclusions. Most of what becomes clear about the mother-namely, that she is a narcissistic personality-becomes clear on account of the piling up of evidence. The reader realizes only retrospectively what the evidence is for. Some of the more obvious faultings of the mother include Sarraute's account of how her mother takes offense at her daughter's innocent remark, around the age of 7, that a hairdresser's mannequin is more beautiful than she. Then, her mother sends her to France to live with her father and fails to collect her when she signals her unhappiness to her in an agreed-on code. She also refuses to let her daughter call her stepmother "mama." On first reading, Sarraute's account of her Parisian exile merely seems to show how much she missed her mother. Retrospectively, it reads like an indictment of her mother for imposing this absence on her daughter. On a second reading, it becomes apparent to what degree Sarraute plays up how heartbroken she was to be parting from her mother-Nathalie sobs and runs after the train carrying her mother as it pulls out of the station in Berlin-and how much she missed her mother in Paris. Moreover, at the end of her account of her mother's treachery in not responding as they had agreed to her coded message, Sarraute, stating that she was "shattered, overwhelmed by the shock" (Sarraute: 101), plants a clue: "I, at that age, I wasn't nine years old, I am sure that everything that was gradually revealed to me, during the ensuing years, I perceived at that moment, at a stroke, en bloc... all my relations with my father, with my mother, with Vera, their own relationships, were only the unraveling of what was then unraveled" (Sarraute: 102).

What was then unraveled? Sarraute does not say, but retrospectively, the reader comes to share Sarraute's hindsight and figures out the solution. Toward the end of the book, Sarraute brings her accusatory agenda to a climax by recounting how her mother came to Paris to visit her after a 2 1/2-year separation, but stormed back to Russia with an air of lèse-majesté when Nathalie opted to go on an excursion with friends one day instead of spending that day with her. This behavior demands to be judged as unreasonable and hurtful. It stands to be condemned. It also gives us a key to the mother's previous behaviors. In retrospect, all of Sarraute's childhood memories of her mother seem bittersweet to the reader, inasmuch as they 
all accommodate the interpretation that her mother lacked love for her daughter, or that her love was not selfless. Sarraute, who published her book when she herself was an old woman and relevant parties were dead, smuggles an accusation against her mother into Enfance that retrospectively taints what at first seemed like innocent memories of her.

Like Kafka's Letter, Sarraute's Enfance amounts to "a monologue disguised as dialogue" (Buber). ${ }^{35}$ Initially, Sarraute sets her dialogue up on the model of the psychoanalytic dialogue, whose objective is to arrive at the truth. As in a Socratic dialogue, one partner (the psychoanalyst) is wiser than the other (the patient), and tries, with the other's consent, to guide the patient to see the light. The psychoanalytic dialogue is supposed to culminate with the patient arriving at self-understanding. Sarraute's autobiography, couched as a fictitious dialogue, initially appears to be headed in that direction. The conversation between her and her psychoanalyst-like interlocutor promises an outcome that is open and unpredetermined. Yet although Sarraute's work shows plenty of selfunderstanding on the part of the author figure, its final point, which is carefully prepared along the way, is a different one: her mother was awful.

Both Kafka and Sarraute suffered from not being "heard" by one of their parents. Each text represents the parent both as the wielder of powerful words-words that have a tremendous effect on the child-and also as one who is deaf to the child. Kafka's powerfully self-confident father and Sarraute's narcissistic mother are non-listeners, non-comprehenders: they filter anything the child says through an ideal image they have imposed on the child, blocking out the actual child. Thus, Kafka's father encouraged Franz to follow directions for which he was not suited, while discouraging him from following his own path: "What I would have needed was a little encouragement, a little friendliness, a little keeping open of my road, instead of which you blocked it for me, though of course with the good intention of making me go another road. But I was not fit for that. You encouraged me, for instance, when I saluted and marched smartly, but I was no future soldier, or you encouraged me when I was able to eat heartily or even drink beer with my meals, or when I was able to repeat songs, singing what I had not understood, or prattle to you using your own favorite expressions, imitating you, but nothing of this had anything to do with my future" (Letter: 17-19). In Enfance, Nathalie's mother demands absolute adoration, making no allowances, for example, for her seven-year-old daughter's inadvertent misstep in saying that a doll is more beautiful than she: "Mama ... looks at me with her displeased expression and says: "A child who loves its mother thinks that no one is more beautiful than she" (Sarraute: 84). Both parents have self-serving expectations of the child that they demand to see fulfilled, at the expense of the actual child. 
Both dialogues can be comprehended as reader-oriented strategies, but they also appear to try to compensate for a past real-life situation. Kafka's letter instantiates the kind of dialogue between himself and his father that never happened in reality. Sarraute's interlocutor figure is an imaginary friend-one who initially speaks in the authoritative, challenging tone reminiscent of her mother but then becomes Sarraute's helper and collaborator. Are these wish fulfillments? These two autobiographical dialogues are certainly compensatory, suggesting a better communicative model than the one their parents inflicted on them when they were children. In adopting the form of the dialogue, therefore, Kafka and Sarraute do not just devise ingenious lawyerly strategies to win their cases. They simultaneously sidestep the model of the unidirectional monologue that brooks no retort, which closely resembles the type of interaction their parents inflicted on them, and develop a model that shows that every issue has more than one side.

\section{ABOUT THE AUTHOR}

Lorna Martens is Professor of German and Comparative Literature at the University of Virginia. She is the author of The Diary Novel (1985); Shadow Lines: Austrian Literature from Freud to Kafka (1996); The Promised Land? Feminist Writings in the German Democratic Republic (2001), and The Promise of Memory: Childhood Recollection and its Objects in Literary Modernism (2011). She has published on authors including Butor, Freud, Musil, Kafka, Rilke, Hofmannsthal, Schnitzler, Valéry, Proust, and Benjamin, and on topics such as memory, poetic style, narrative theory and technique, psychoanalysis, and aesthetics. She is currently writing a book on women's childhood autobiographies worldwide.

\section{NOTES}

1 Bertolt Brecht, "An die Nachgeborenen," Ausgewählte Gedichte (Frankfurt am Main: Suhrkamp, 1964), 56. My translation.

2 Joanna Richardson, Enid Starkie (London: John Murray, 1973), 134-136.

3 Athénaïs Michelet's mother died on 13 November 1864; Athénaïs started writing her childhood memoirs, Mémoires d'une enfant (1866), on 13 September 1865, according to Jules Michelet, Journal III, ed. Claude Digeon (Paris: Gallimard, 1976), 268, 343.

4 Claire Martin, In an Iron Glove: An Autobiography, trans. Philip Stratford, Introduction by Patricia Smart (Ottawa: University of Ottawa Press, 2006), xviii.

5 Martin, Iron Glove, 3.

6 Martin, Iron Glove, xviii.

7 Max Brod, Franz Kafka: Eine Biographie (Frankfurt a.M: S. Fischer Verlag, 1962 [c. 1954 Schocken Books], 23. "Trotz seines Umfangs von mehr als hundert Seiten war der Brief, wie ich aus den Gesprächen mit Franz bezeugen kann, dazu bestimmt, dem Vater wirklich übergeben zu werden (und zwar durch die Mutter), und Franz hatte eine Zeitlang die Meinung, durch diesen Brief eine Klärung der peinlich stockenden, schmerzhaft verharschten Beziehung zum Vater herbeizuführen." 
8 Brod, Franz Kafka, 23.

9 Hartmut Binder, Kafka-Kommentar zu den Romanen, Rezensionen, Aphorismen und zum Brief an den Vater (München: Winkler, 1982), 426.

10 See Anatol Regnier, Frank Wedekind: eine Männertragödie (München: Random House, 2010), 72; Patrick Bridgwater, Poet of Expressionist Berlin: The Life and Work of George Heym (London: Libris, 1991), 4; Miriam Raggam, Walter Hasenclever: Leben und Werk (Hildesheim: Gerstenberg, 1973), 1-3; Jürgen Haupt, Gottfried Benn, Johannes R. Becher (n.p.: Europäische Verlagsanstalt, 1994), 94-96; see also David F. Kuhns, German Expressionist Theatre: The Actor and the Stage (Cambridge: Cambridge University Press, 1997), 36-37 and 254 note 39.

11 Lois Palken Rudnick, Mabel Dodge Luhan: New Woman, New Worlds (Albuquerque: University of New Mexico Press, 1984), 256.

12 Elaine Showalter, "Towards a Feminist Poetics," in Women Writing and Writing About Women, ed. Mary Jacobus (London: Croom Helm, 1979), 22-14; here, 32.

13 Marianne Hirsch, "Mothers and Daughters," Signs 7, No. 1 (1981), 200-222 gives an overview of the theories.

14 Nathalie Sarraute, "De Dostoievski à Kafka," in L'Ère du soupçon (Paris: Gallimard, 1959), 9-52 (first published in Temps Modernes, 1947). Translated into English as "From Dostoievski to Kafka," in The Age of Suspicion (New York: Braziller, 1963), 11-50.

15 Leah D. Hewitt, Autobiographical Tightropes (Lincoln, NE: University of Nebraska Press, 1990), 70-71

16 James M. Honeycutt, Imagine That: Studies in Imagined Interactions (Cresskill, NJ: Hampton Press, 2010), 12.

17 Martin Buber, Between Man and Man, trans. Ronald Gregor Smith (Routledge \& Kegan Paul, 1947), 22, 19.

18 Honeycutt, Imagine That, 195.

19 David Bohm, On Dialogue, ed. Lee Nichol (London: Routledge, 1996), 7.

20 Bohm, On Dialogue, 26.

21 Bohm, On Dialogue, 17.

22 Rob Anderson, The Martin Buber - Carl Rogers Dialogue: A New Transcript with Commentary (Albany: SUNY Press, 1997), 72.

23 Honeycutt, Imagine That, 6.

24 Honeycutt, Imagine That, 202.

25 Gilles Deleuze and Félix Guattari, Kafka: Toward a Minor Literature, trans. Dana Polan (Minneapolis: University of Minnesota Press, 1986), 30.

26 Franz Kafka, Letters to Milena, trans. Philip Boehm (New York: Schocken, 1990), 223.

27 E.g. by Kate Flores, "The Judgment," (first pub. 1947) in Franz Kafka Today, ed. Angel Flores and Homer Swander (Madison, WI: University of Wisconsin Press, 1964) 5-24: here 22-23; Walter H. Sokel, Franz Kafka: Tragik und Ironie (first pub. 1964) (Frankfurt a.M.: Fischer, 1983), 7 et passim; Frederick J. Beharriell, "Kafka, Freud, and Das Urteil," in Texte und Kontexte: Studien zur deutschen und vergleichenden Literaturwissenschaft. Festschrift für Norbert Fuerst, ed. Manfred Durzak, Eberhard Reichmann, and Ulrich Weisstein (Bern: Francke, 1973), 27-47: here 35; Marthe Robert, As Lonely as Franz Kafka (orig. 1979), trans. Ralph Manheim (New York: Schocken, 1986), 11, 28-30, 43-45; and Hartmut Binder, Kafka-Handbuch, ed. Hartmut Binder (Stuttgart: Kröner, 1979), I: 160. Christoph Stölzl, noting that psychoanalysis is biographical (525), summarizes the various psychoanalytical approaches to the Letter in Kafka-Handbuch, ed. Hartmut Binder (Stuttgart: Kröner, 1979), II: 522-525. In contrast, some critics, above all more recent critics, have given the formal qualities of the Letter closer scrutiny. Lawrence Ryan, "'Zum letztenmal Psychologie!' Zur psychologischen Deutbarkeit der Werke Franz Kafkas," in Psychologie in der Literaturwissenschaft, ed. Wolfgang Paulsen (Heidelberg: Lothar Stiehm 
Verlag, 1971), 157-173, notes that the Letter denies the communicative purpose of its genre by making the partner a "Resonanzboden der eigenen Subjektivität" (164). Walter Müller-Seidel, "Kafkas Brief an den Vater. Ein literarischer Text der Moderne," Orbis Litterarum 42 (1987): 353-374, observes that Kafka exaggerates, gives his father's thoughts, and contradictorily produces an accusation while declaring his father free from guilt. Marjanne E. Goozé. "Creating Neutral Territory: Franz Kafka's Purloined Letter to His Father," Journal of the Kafka Society of America, $11^{\text {th }}$ Year (1987): 28-39, calls attention to the literariness and also to the dialogue structure of the letter, noting that Kafka had an epistolary theory that involved split subjects and phantom addressees (30), as opposed to the simple effort to involve understanding with a partner. She cites Kafka's letter to Milena in which he designates epistolary correspondence a "Verkehr mit Gespenstern" (29).

28 Franz Kafka, Letter to his Father/Brief an den Vater, trans. Ernst Kaiser and Eithne Wilkins (New York: Schocken, 1953), 87.

29 Franz Kafka, Briefe an Milena, ed. Willy Haas (Frankfurt a.M: S. Fischer Verlag, 1981), 61. "Morgen schicke ich Dir den Vater-Brief in die Wohnung, heb ihn bitte gut auf, ich könnte ihn vielleicht doch einmal dem Vater geben wollen. Laß ihn womöglich niemand lessen. Und verstehe beim Lesen alle advokatorische Kniffe, es ist ein Advokatenbrief" [undated letter apparently written in July 1920]. Binder, Kafka-Kommentar, 426, believes that he did not give it to her, at least not in summer 1920.

30 Most critics of Enfance focus on the form, the construction, the tropisms, the language, the theme of words, the self-referentiality, and the connections to Sarraute's previous work. These include, for example, Valerie Minogue, "Fragments of a Childhood," Romance Studies 5 (1986): 71-83; Valerie Minogue, "Nathalie Sarraute's Enfance: From Experience of Language to the Language of Experience," Studies in French Fiction in Honour of Vivienne Milne, ed. Robert Gibson (n.p.: Grant \& Cutler Ltd., 1988), 209-224; Philippe Lejeune, "Paroles d'enfance," Revue des sciences humaines 217 (1990), 23-38; Monique Gosselin, "Enfance de Nathalie Sarraute: les mots de la mère," Revue des sciences humaines 222 (1991), 121-142; Barbara Havercroft, "Lautobiographie comme reprise: l'exemple d'Enfance de Sarraute," Tangence 42 (1993), 131-145; Johnnie Gratton, "The Present Tense in Nathalie Sarraute's Enfance," French Studies Bulletin 52 (1994), 15-17; Johnnie Gratton, "Autobiography and Fragmentation," Nottingham French Studies 34, No. 2 (1995), 31-40; and Johnnie Gratton, "Towards Narrativity: Nathalie Sarraute's Enfance," Forum for Modern Language Studies 31 No. 4 (1995), 300-310. Raylene L. O'Callaghan, "Reading Nathalie Sarraute's Enfance: Reflections on Critical Validity," Romanic Review 80:3 (1989), 445-461 critiques Yolanda Patterson for foregrounding in an 1986 MLA paper Sarraute's unhappy childhood and lack of a loving mother, which to O'Callaghan's mind was an overly simplistic reading.

31 Philippe Lejeune points out that the interlocutor is gendered masculine in the first episode ("grandiloquent" and "outrecuidant" are the masculine forms of the adjectives). Philippe Lejeune, "Paroles d'Enfance," Revue des sciences humaines 217 (1990): 23-38, here 32 .

32 Nathalie Sarraute, Childhood, trans. Barbara Wright (New York: Braziller, 1984 [orig. French 1983]), 1.

33 Serge Doubrovsky, "Autobiography/ Truth/ Psychoanalysis," trans. Logan Whalen and John Ireland, Genre 26:3 (1993), 27-42, here 37.

34 "J'ai toujours détesté la psychanalyse," she told Simone Benmussa in an interview. Simone Benmussa, Nathalie Sarraute, Qui êtes-vous? (Lyon: La Manufacture, 1987), 44.

35 Between Man and Man, 19. 